\title{
In vivo three-dimensional structural analysis of cilia by cryo-electron tomography
}

\author{
T Ishikawa*, KH Bui, T Movassagh, G Pigino, A Maheshwari \\ From First International Cilia in Development and Disease Scientific Conference (2012) \\ London, UK. 16-18 May 2012
}

Ciliary bending motion is driven by sliding of microtubule doublets with dynein molecular motors. Dyneins form two complexes: inner and outer dynein arms. The inner arm is supposed to determine the waveform, while the outer arm is likely an accelerator. However, the mechanism to integrate linear motion of dynein into well-orchestrated axonemal bending is still to be investigated. We are analyzing 3D structure of cilia from Tetrahymena, Chlamydomonas, sea urchin sperm and mouse trachea, to reveal the novel architecture of cilia. By comparing 3D structure of Chlamydomonas mutant axonemes, we located all the three outer arm dyneins and the eight inner arm dyneins (Bui et al. (2008) J. Cell Biol. 183, 923). Dyneins, which consist of the N-terminal tail, the ATPase ring, the stalk and the microtubule binding domain, undergo conformational change during the phosphate release: the ATPase ring shifts $8 \mathrm{~nm}$ toward the distal end, which can explain the minus-end driven motor activity of dynein. Interestingly, in vivo, some dyneins change their conformations, while the other stay in the apo form, suggesting negative cooperativity among dyneins and bending mechanism caused by torsion at the boundary between dynein in the apo form and in the nucleotide-binding form (Movassagh et al. (2010) Nat. Struct. Mol. Biol. 17, 761). We also reconstructed 3D structure of the radial spoke, regulatory complex of 23 proteins (Pigino et al. (2011) J. Cell Biol. 195, 673). Each radial spoke has pseudo-two fold symmetry, indicating dimeric nature. Our 3D structure implies the assembly pathway of the radial spoke.

http://www.psi.ch/lbr/takashi-ishikawa

Published: 16 November 2012

\footnotetext{
* Correspondence: takashi.ishikawa@psi.ch
}

Paul Scherrer Institute, Switzerland

( ) 2012 Ishikawa et al; licensee BioMed Central Ltd. This is an Open Access article distributed under the terms of the Creative Commons Attribution License (http://creativecommons.org/licenses/by/2.0), which permits unrestricted use, distribution, and reproduction in any medium, provided the original work is properly cited.
doi:10.1186/2046-2530-1-S1-P25

Cite this article as: Ishikawa et al:: In vivo three-dimensional structural analysis of cilia by cryo-electron tomography. Cilia 2012 1(Suppl 1):P25.

Submit your next manuscript to BioMed Central and take full advantage of:

- Convenient online submission

- Thorough peer review

- No space constraints or color figure charges

- Immediate publication on acceptance

- Inclusion in PubMed, CAS, Scopus and Google Scholar

- Research which is freely available for redistribution

\section{C) Biomed Central}

